\title{
Föräldrars och ungdomars erfarenheter av \\ familjebehandling inom socialtjänsten
}

CHRISTINA LÖWENBORG \& YVONNE SJÖBLOM

Det finns samspelsmönster som underlättar och andra som försvairar att hjälp ska komma till stånd. I denna artikel delger föräldrar och ungdomar sina erfarenheter och upplevelser av familjebehandling inom socialtjänsten.

\begin{abstract}
Inledning
Familjebehandling är idag en vanligt förekommande insats inom kommunernas individ- och familjeomsorg. Många kommuner har valt att inrätta särskilda familjebehandlingsgrupper för att kunna erbjuda familjer hjälp och stöd på hemmaplan. Syftet är dels att mobilisera familjens och nätverkets egna resurser för att lösa en

Christina Löwenborg, FoU-assistent, FoU-Nordväst, Stockholm

Yvonne Sjöblom, fil. dr i socialt arbete vid institutionen för socialt arbete - Socialhögskolan, Stockholms universitet
\end{abstract}

uppkommen problematik och dels för att förebygga och undvika mer omfattande insatser som t.ex. omhändertaganden av barn och ungdomar.

Relationsproblem inom familjen tillhör idag ett av de vanligaste problemområdena som socialsekreterare möter och arbetar med. Familjebehandling i olika former är följaktligen också en av de vanligaste insatserna som erbjuds dessa familjemedlemmar som hjälp. Trots detta visar det sig att kunskapen om denna insats och hur familjerna upplever den är så gott som obefintlig. Vi vill med den här artikeln redogöra för några aspekter av en större studie som studerade vilka familjer som mottog familjebehand- 
ling i två Stockholmskommuner och hur ett urval av dem upplevde behandlingen och samspelet mellan hjälparen och den hjälpsökande. ${ }^{1}$

\section{Syfte och frågeställningar}

Denna artikel syftar till att undersöka hur föräldrar och ungdomar som mottagit insatsen familjebehandling upplevde samspelet mellan familjebehandlaren och dem själva. Frågeställningarna som studerades var: vilka samspelsmönster som ungdomarna och föräldrarna upplevde som hjälpsamma samt vilka samspelsmönster som upplevdes som hinder för att få hjälp.

\section{Bakgrund och tidigare forskning}

Begreppet familjebehandling ingår $\mathrm{i}$ det vidare begreppet "behovsprövat personligt stöd», som utgör några av de insatser som individ- och familjeomsorgen inom socialtjänsten arbetar med. De vanligaste insatserna inom den sociala barnavården är familjeterapi, familjebehandling och hemma-hos-behandling (Tengvall 2000). Följande tre aspekter bör ingå i behandlingen för att det ska kallas familjebehandling: dels att behandlingen riktar sig mot familjer, dvs. målgruppen definierar

1 Den familjbehandling som intervjupersonerna i denna studie deltagit $i$ har bestått av systemteoretiskt familjearbete med inslag av arbete med reflekterande team, marte-meo- och nätverksarbete. Arbetet med familjer har huvudsakligen skett tillsammans med två familjebehandlare. behandlingen. Dels att det handlar om ett specifikt synsätt där utgångspunkten är att man ska förstå eller påverka ett system. Och till sist att behandlingen utgår från teorier med ett interpersonellt perspektiv som utgångspunkt, till skillnad mot teorier med ett intrapsykologiskt perspektiv (Hansson 2001). Familjebehandling kan betraktas som en paraplybeteckning för flera olika slags insatser som erbjuds av kommunernas individ- och familjeomsorg. Insatserna kan bestå av familjesamtal, samspelsbehandling mellan föräldrar och barn, enskilt stöd till barn, ungdomar eller föräldrar, nätverksarbete, familjerådslag och handledning till familjehem och jourhem.

Familjebehandlingsfältet uppstod under 1970-talet då det individuella arbetssättet förändrades till att ta in fler medlemmar ur familjen i behandlingen. Motivet bakom förändringen handlade om att individuell behandling ansågs vara otillräcklig. Familjebehandlingen i sin tur hade sin bakgrund i influenser från nya teoretiska inriktningar som kommunikations- och systemteori. Idag finns närmare 250 olika inriktningar inom familjebehandlingsfältet. Dagens teoretiska utveckling verkar gå mot en högre grad av integrering där olika teoretiska modeller blandas i en eklektisk och pragmatisk anda (Hansson 2001).

Enligt Hansson (2001) saknas det idag forskning om familjebehandling som insats för att hjälpa familjer som socialtjänsten kommer i kontakt med. En översikt över tillgänglig internationell forskning av familjebehandling (Statham 2000) visar att det råder brist på väldesignade studier som studerar effektiviteten av interventionen familjebehandling. Särskilt 
betonas behovet att utifrån en kvalitativ utgångspunkt studera familjemedlemmars egna såväl som professionellas upplevelser av familjebehandling. Denna ansats har således varit vägledande i designen av den studie som ligger till grund för den här artikeln med begränsningen att vi endast har utgått från föräldrars och ungdomars perspektiv av familjebehandling. Utifrån den internationella forskningsöversikten blir det tydligt att det svenska begreppet "familjebehandling" skiljer sig från andra liknande anglosaxiska begrepp. I USA görs en klar distinktion mellan "family support" och "family preservation". "Family support" riktar sig till familjer som handskas med normal stress i föräldraskapet, förbereder dem på nya påfrestningar och syftar till att förebygga allvarligare psykosocial problematik. "Family preservation" är ytterligare en annan insats med syfte att understödja riskfamiljer vid allvarliga kriser. Vanligtvis är denna insats endast tillgänglig för de familjer vars problem gjort dem aktuella hos sociala myndigheterna, rättsystemet eller psykiatrin (Statham 2000). "Family support" är en insats riktad mot så kallade sårbara grupper och för tidig upptäckt av svårigheter eller temporära kriser i familjen. Däremot är det inte en insats riktad till familjer med djupare och allvarligare stresspåverkan, där risk för familjens upplösning kan föreligga eller där barn redan var omhändertagna av sociala myndigheter (Hardiker et al. enligt Statham 2000). "Family support" täcker delvis ett annat fält jämfört med det svenska begreppet familjebehandling, som exempelvis behandling och stöd som kan ges vid familjecentraler, i förskola, genom föräldrautbildning, i familjerådslag. Eller genom olika interventioner för att befrämja barns psykiska hälsa och jourhemsvistelser för barn.

Det svenska begreppet familjebehandling kan således beskrivas som en insats som delvis är överlappande med de bägge begreppen "family support" och "family preservation". I Stathams (2000) översikt av tillgängliga undersökningar inom fältet görs ett antal tentativa konklusioner om vilken typ av stöd som är effektivt för att hjälpa familjer med problem. Det finns enligt forskningen belägg för att ett fåtal av föräldraprogrammen leder till förändring över tid, speciellt de gruppbaserade som hjälper föräldrar att utveckla positiva inriktade förstärkningstekniker. Stöd i hemmiljön visar sig ha positiva effekter på mor-barn interaktionen samt på moderns allmänna välbefinnande. En nyckelaspekt som uppmärksammas i forskningen om framgångsrika interventioner är på vilket sätt stödet ges och kvalitén på relationen mellan den som ger och den som tar emot hjälp (Statham 2000). Detta bekräftas också $\mathrm{i}$ en studie som behandlar relationen mellan socialarbetare och klienter inom den sociala barnavården. I den framkommer att ett gott samarbete mellan socialarbetare och klient som bygger på ett humanistisk förhållningssätt också kan ha terapeutiska implikationer för klienten även vid komplexa och svåra fall (Boer \& Coady 2007). Resultaten från den tidigare internationella forskningen måste dock appliceras med försiktighet i andra sociala välfärdskontexter. Det bör också framhållas att den sociala barnavården och dess interventioner aldrig endast kan reduceras till 
en fråga om vetenskapligt kunskap. Moral, socialpolitik och kulturella föreställningar om vad en god socialarbetare, en god förälder och en god barndom är påverkar också den sociala barnavården (Sundell \& Egelund 2001).

Eftersom syftet med den här artikeln är att undersöka hur brukare (föräldrar och ungdomar) inom socialtjänsten som mottar insatsen familjebehandling upplever samspelet mellan dem själva och behandlaren vill vi också kortfattat beröra betydelsen av ett brukarperspektiv i forskning. Som brukare bidrar man med sin unika kunskap som utgår från ett självupplevt perspektiv. Det ersätter inte men kan vara ett viktigt komplement till ett professionellt och vetenskapligt perspektiv. Den kunskap som brukare bidrar med kan skapa ökad förståelse för deras upplevelser av exempelvis en viss behandling eller ett visst socialt förhållande.

I allt socialt arbete är maktaspekter viktiga. Att anlägga ett brukarperspektiv kan bidra till att maktstrukturer tydliggörs, att frågor om roller mellan socialarbetare och klient analyseras och hur olika aktörers handlingsutrymme uppfattas utifrån ett brukarperspektiv (Socialstyrelsen 2003). Brukarperspektivet är starkt knutet till begreppet empowerment som kan översättas till bemyndigande och bemäktigande. Att som brukare vara delaktig i forskning som bedrivs om den egna livssituationen och få möjlighet att delge sina erfarenheter av exempelvis en behandling som man tar del av anses kunna bidra till ökat inflytande och empowerment för brukaren (Starrin \& Jönsson 2000).

\section{Studien som ligger till grund för artikeln}

I studien "Med andra ögon- brukarens syn på familjebehandlingu studerades familjers erfarenheter av insatsen familjebehandling (Löwenborg \& Kamsvåg 2006). Studien bedrevs under en tvåårsperiod i två kommuner i nordvästra Stockholm. Resultaten från några delar av den kvalitativa delen av studien ligger till grund för den här artikeln. Studien i sin helhet innehåller både en kvantitativ (delstudie ett) och en kvalitativ studie (delstudie två). Delstudie ett omfattas av en totalundersökning där journaler rörande 268 barn som med sina respektive familjer deltagit i familjebehandling har studerats. Delstudie två omfattas av en intervjustudie med ett slumpmässigt urval från populationen i delstudie ett. Sammanlagt har 18 personer intervjuats i delstudie två.

\section{Sammanfattning av journalstudien med 268 barn (delstudie 1)}

Syftet med den kvantitativt inriktade delstudien var att kartlägga målgruppen som fick insatsen familjebehandling och beskriva några karaktäristika som definierade den. I delstudien undersöktes olika bakgrundsfaktorer och deras inbördes samband utifrån studier av journalanteckningar till samtliga familjer som i två kommuner i nordvästra Stockholm genomgått familjebehandling under åren 2000-2001. Resultaten från journalstudien visade att ensamstående förälder med företrädelsevis

Löwenborg \& Sjöblom: Föräldrars och ungdomars erfarenheter... 
en mamma med barn i skolåldern tillhörde den dominerande gruppen av familjer som fick insatsen familjebehandling. Generellt kan man säga att den sociala problematik som framträdde i journalerna kännetecknades av relations- och skolproblem. Två olika åldersgrupper barn kunde urskiljas i bearbetningen av materialet. Det var dels de yngre barnen i åldern 8-12 år med skolproblem. Den andra gruppen bestod av de äldre barnen i åldern 13-17 år, med relations- och skolproblem. Dessa bägge grupper utgjorde sammanlagt en tredjedel av hela populationen barn i undersökningen. Könsfördelningen var jämn med någon övervikt av flickor.

Närmare hälften av barnen hade minst en utlandsfödd förälder och när så var fallet saknade barnet ofta kontakt med en förälder som vanligtvis var fadern. Kontakten med socialtjänstens individ- och familjeenhet hade åstadkommits på initiativ av socialsekreterare som familjen hade en tidigare kontakt med och som hade remitterat dem till familjebehandlingsenheten. Insatsen familjebehandling gavs av kommunens interna behandlingsresurs och varade under ett år och avslutades därefter oftast på familjens initiativ.

Familjerna hade, förutom aktuell familjebehandling, ofta erfarenhet av tidigare behandlingsinsatser samt även andra pågående parallella stödinsatser. Populationen i denna studie bekräftar bilden av tidigare forskning om att de familjer som kommer i kontakt med den sociala barnavården tillhör en resurssvag och socialt utsatt grupp av befolkningen (Sundell \& Egelund 2001).

När vi nu hade samlat in en deskriptiv bild av vilka familjer som var aktuella för insatsen familjebehandling gick vi vidare och studerade i den kvalitativa delen av studien hur några av familjerna från delstudie ett hade upplevt familjebehandlingen.

\section{Intervjustudie med ungdomar och föräldrar (delstudie 2)}

Den kvalitativa delstudien bestod av 18 informanter som deltog i fokusgrupper och i individuella intervjuer. De valdes ut utifrån ett slumpmässigt urval från de 268 familjerna som populationen i delstudie ett utgjordes av. De 18 personerna i delstudie två var sammantaget fem mödrar, fem fäder och åtta ungdomar av kvinnligt kön. Syftet med den kvalitativa delstudien var att få en bild av familjemedlemmarnas upplevelser av familjebehandlingen och samspelet mellan hjälparen och den hjälpsökande. Intervjuerna syftade till att få kunskap om informanternas subjektiva upplevelser av familjebehandlingen och hur de uppfattade samspelet mellan dem själva och hjälparen.

\section{Metod}

Fokusgrupp som intervjumetod användes i studien. Den är lämplig när man vill ta reda på hur människor tänker kring ett visst fenomen och lämpar sig för komplexa frågeställningar genom att målgruppen fritt i grupp får formulera sig kring ett tema (Wibeck 2000). En grundläggande idé är att interaktionen i fokusgruppen genererar nya tankar och att summan av gruppens erfarenheter och tankar därmed är något annat än enskilda gruppmedlem- 
mars. Det har även visat sig att metoden är lämplig att använda vid studier av frågor som berör svåra känslomässiga teman, med socialt komplexa frågeställningar och med grupper av informanter som kan anses vara marginaliserade och som därför ofta inte kommer till tals inom forskning (Överlien et al. 2005).

I denna studie genomfördes tre olika fokusgrupper; en med mödrar, en med fäder och en med ungdomar. Dessutom genomfördes kompletterande individuella intervjuer med sammanlagt sju informanter med samma teman som i fokusgrupperna. Fokusgrupp ett bestod av fem mammor där endast en gav återbud. Det var svårare att samla fäderna till fokusgrupp två. De hade svårt att avsätta tid även om intresse fanns. Sammanlagt blev det av ursprungligen sex tillfrågade fäder två som slutligen kom till fokusgruppen. Studien kompletterades med tre individuella intervjuer med de fäder som tidigare lämnat återbud. En pappa uteblev alltså helt från både fokusgrupp och intervju. Till fokusgrupp tre med ungdomar gjordes två urval som omfattades av sammanlagt 22 ungdomar. Fyra flickor valde att delta i fokusgruppen och ytterligare fyra flickor intervjuades individuellt. Samtliga sex pojkar från bägge urvalen avböjde helt att delta i studien. Förutom bortfallet av pojkar var det åtta flickor som varken ville delta i fokusgrupp eller bli individuellt intervjuade.

\section{Bortfallsanalys och metodologiska överväganden}

Vid analys av bortfallet framkom att två pojkar var omhändertagna för samhällsvård vid tidpunkten för fokusgruppsintervjun. En annan pojke kunde inte minnas att han hade genomgått familjebehandling. Ytterligare en pojke gick inte att nå per telefon trots upprepade försök. En annan pojke avböjde att delta på grund av missnöje med socialtjänsten och ytterligare en tackade nej utan motiv. Bland flickorna i bortfallet framkom att de inte ville delta i gruppintervjuer med andra flickor på grund av rädsla för att blotta sig. Med dem genomfördes därför enskilda intervjuer för att ta hänsyn till detta. Övriga flickor i bortfallet som inte deltog angav motiv som att de inte hade tid eller motivation för att delta i studien. Bortfallet var alltså störst bland ungdomarna.

En brist i studien är att endast flickor intervjuats. Resultaten från studien hade blivit mer mångfacetterade om också pojkarnas upplevelser hade kunnat studeras. Bortfallet bland ungdomarna visar på känsligheten i den studerade frågan och därmed svårigheten att få tillgång till dessa informanters upplevelser om familjebehandling.

I denna studie framgår också att kombinationen av fokusgrupp och individuella intervjuer blev nödvändig för att kunna minimera bortfallet så mycket som möjligt och kan möjligtvis ifrågasätta fokusgruppsmetodens lämplighet i förhållande till känslomässigt svåra teman som upplevelser av familjebehandling. Några ungdomar visade tydligt att de hade farhågor att dela sina upplevelser med andra och vi kan anta att detta även kan gälla för de vuxna som inte ville delta i grupperna. De som däremot deltog uttryckte att de kände stöd från gruppen och att det var till hjälp för dem 
själva att dela med sig av sina upplevelser till andra.

Utifrån forskningsetiska principer inbjöds inte yngre barn under 13 år då frågeställningarna rörde känsliga och svåra områden. Hos de ungdomar som var under 18 år inhämtades föräldrars godkännande att delta.

Fokusgruppsintervjuerna varade tidsmässigt två timmar och genomfördes av två intervjuare. De individuella intervjuerna varade c:a 60 min och genomfördes av en av de två intervjuarna. Samtliga intervjuer spelades in på band och transkriberades.

\section{Genomförande av fokusgrupperna och intervjuerna}

I fokusgrupperna behandlades teman som förändring under familjebehandlingen, hur problemet hade utvecklats under behandlingen och den viktigaste erfarenheten under familjebehandlingen. Vad upplevdes som hjälpsamt och vad saknades under behandlingen. Dessa teman var också underlag för de enskilda intervjuerna.

De tre intervjugrupperna bestod av mödrar, fäder och ungdomar i separata grupper. Informanterna fick på så sätt möjlighet att diskutera med andra mödrar, fäder och ungdomar som deltagit i familjebehandling om liknade erfarenheter. Att skapa nya konstellationer av grupper genomfördes utifrån föreställningen om att det skulle ge informanterna en större frihet att uttrycka sina upplevelser i ett nytt sammanhang som var annorlunda än den konstellation som de varit i under familjebehandlingen. Sammansättningen av gruppen hoppades vi också skulle tydliggöra gemensamma upplevelser utifrån roll och kön.

\section{Bearbetning och analys}

Alla de transkriberade intervjuerna granskades med fokus på att hitta relevanta teman. De omarbetades och kategoriserades sedan till sin slutgiltiga form i tre större dimensioner som innehöll flera olika underliggande kategorier. De tre dimensionerna var bemötande, återhämtning och handling. Dessa arbetades fram i en induktiv process där de teoretiska utgångspunkterna tjänade till att fördjupa och tydliggöra bearbetningen av empirin.

I denna artikel behandlas temat bemötande eftersom det ger empirisk kunskap om samspelsmönster som informanterna upplevde som hjälpsamma respektive som hindrande för hjälp. Vid analysen av materialet har hänsyn tagits till att två olika intervjumetoder har använts. Det resulterade i att analysen gjordes utifrån de enskilda informanternas utsagor och inte på gruppnivå.

\section{Informanterna}

Samtliga namn är fingerade för att skydda intervjupersonernas identitet. Gruppen män bestod av Adam, Pelle, Mario, Philip och Andreas, fem män i åldern 35-50 år. De var gifta eller sammanboende med barnets mamma. Alla utom en i gruppen var svenskfödda. Övervägande del av dem hade arbete. Några hade tidigare haft bekymmer 
i livet vilket föranlett kontakt med myndighet och behandling. Det kunde då ha handlat om psykiska besvär, alkohol eller relationsbekymmer, medan det för andra var första gången som de kom $i$ kontakt med socialtjänsten. Ungefär hälften hade sökt hjälp själva. De andra hade blivit erbjudna familjebehandling av socialsekreterare. Det var vanligt med erfarenheter av relationsproblem i familjen. De flesta i gruppen hade mer än ett barn. Några var föräldrar till barn med så kallade bokstavsdiagnoser.

Gruppen kvinnor bestod av Karin, Elna, Monika, Harriet och Lydia. Gruppen kvinnor bestod av fem personer, samtliga i åldern 35-55 år. De var svenskfödda med undantag av två personer. De levde ihop med barnets fader förutom en som var ensamstående. I stort sett hade alla arbete. De flesta var mödrar till ungdomar, medan någon också hade mindre barn. Mödrarna hade vanligtvis flera barn. Det var vanligt att mödrarna hade erfarenhet av att ha haft sitt barn omhändertaget. Samtliga hade varit sjukskrivna på grund av utmattningssymtom i samband med ett aktuellt bekymmer och de sammankopplade sin egen utmattning med det. Kvinnorna hade lång erfarenhet av att brottas med myndigheter för att få rätt slags hjälp. Några i gruppen hade tidigare erfarenhet av en hjälpinsats i form av behandling.

Gruppen ungdomar bestod av Veronika, Sarah, Ellen, Sandra, Anne, Mikaela, Emma och Julia, samtliga i åldern 15-21 år. De hade alla erfarenhet av relationsproblem inom familjen och flera hade haft problem i skolan. Alla utom en av ungdomarna hade levt med en ensamstående förälder eller i en ny familjebildning. De saknade kontakt med fadern. En mindre del av dem hade så kallade bokstavsdiagnoser. Några hade erfarenhet av missbruk och andra hade varit utsatta för sexuella övergrepp och misshandel. I gruppen fanns ungdomar som hade ett självskadebeteende, ätstörningar och andra hade varit på rymmen hemifrån av olika anledningar.

Knappt hälften av informanterna hade någon från sin egen familj representerad $\mathrm{i}$ någon av de andra intervjugrupperna.

\section{Teoretiska utgångspunkter}

Som teoretiska utgångspunkter har vi framförallt använt oss av det Anderson (2002) och Carlsson (2003) har skrivit om samspelsprocesser i familjebehandling och i socialt arbete. Anderson tar sin utgångspunkt från sina kliniska erfarenheter som familjeterapeut och Carlsson utifrån sin forskning om hjälpprocesser i socialt arbete.

Anderson har konstruerat ett antal teser utifrån det socialkonstruktivistiska perspektivet med fokus på relationen mellan den hjälpsökande och hjälpare. Hennes teoretiska perspektiv utgår från att mänskliga system är relationella och baserade på språklig interaktion. Teserna utgår från den terapeutiska processen, villkoren för förändring och vad och vem som ska behandlas i den terapeutiska kontexten.

Ur denna synvinkel är den hjälpsökande och hjälparen ett system där människor skapar mening tillsammans. Utgångspunkten är att den verklighet och dess betydelse som tillskrivs oss själva och andra och erfarenheterna i våra liv, är växelverkande 
fenomen, som genom språket skapas och upplevs av enskilda individer i samtal och handling. Språk är skapande, ger livet och världen ordning och mening och fungerar som en form för social delaktighet.

För att förstå, ur ett socialkonstruktivistiskt perspektiv, att samtal havererar utgår Anderson från begreppet duellerande verkligheter. Det innebär att det bara finns ett sätt att betrakta världen, bara en sanning att uppdaga och att det kan uppstå en kamp om tolkningsföreträdet om vems sanning som ska gälla (Anderson 2002).

En annan teoretisk utgångspunkt är de handlings- och samspelsmönster mellan hjälparen och den hjälpsökande som ingår i en begreppsstruktur som Carlsson (2003) beskrivit. Han har konstruerat ett kluster av olika handlingsmöjligheter utifrån sina studier av hjälpprocesser i socialt arbete. Begreppet samsyn definierar den handlingsmöjlighet som uppstår när den hjälpsökandes syn på det aktuella problemet överensstämmer med hjälparens.

En annan handlingsmöjlighet är pseudoanpassning. Det innebär att den hjälpsökande anpassar sig till situationen på så vis att han spelar med i den professionelles definition av problemet. Den hjälpsökande kan dölja vissa problem och anpassar sig skenbart pga. exempelvis rädsla för att bli utsatt för olika tvångsåtgärder. Den hjälpsökandes försök att förhålla sig till den asymmetriska relationen mellan sig själv och hjälparen kan leda till en gisslanroll i processen vilket i sin tur kan resulterar i ett passivt förhållningssätt hos den hjälpsökande (Carlsson 2003).

Ytterligare en av de aspekter som påverkar samspelet är begreppet förstruktur hos aktörerna, framför allt förstrukturen hos hjälparen. Med begreppet avses de erfarenheter och de kunskaper som fungerar som ett raster i mötet med den andre. Hjälparens förstruktur riskerar bli en dominerande diskurs på grund av att hjälparen och den hjälpsökande har en asymmetrisk relation. En avgörande punkt i samspelsprocessen mellan den hjälpsökande och hjälparen är den process då problemet ska benämnas, bestämmas och definieras, dvs. problembestämningsprocessen (Anderson 2002). Förstrukturen har en avgörande inverkan på problembestämningsprocessen, som i sin tur påverkar utvecklingen av olika samspelsmönster.

\section{Resultatredovisning}

De empiriska resultaten kommer i resultatredovisningen att presenteras och kopplas till teoretiska begrepp som beskriver samspelet mellan hjälparen och den hjälpsökande.

I intervjuerna framträder ett flertal utsagor, som rörde samspelet mellan den hjälpsökande och hjälparen. Det handlade om hur den som tagit emot familjebehandlingen uppfattade relationen till hjälparen och det har kategoriserats under temat bemötande och syftar på hur hjälpprocessen tolkades av parterna.

I förhållande till temat bemötande talade de intervjuade om betydelsen av ett gemensamt undersökande av problemet där olika samspelsmönster utvecklades så som samverkande-, duellerande- och pseudoanpassningsmönster. Därutöver kommer begreppen; supplementation, problembe- 
stämningsprocess, förstruktur och dialogisk rymd, som också är kopplade till temat bemötande att behandlas i resultatredovisningen.

\section{Samverkan, samsyn och samklang}

Dessa samspelsmönster upplevdes av informanterna som verksamma och ledde till upplevelser av ett positivt samspel. Så här uttryckte Veronica sin upplevelse av hälp och ett samverkande samspelsmönster och hur det uppfattades som hjälpsamt:

Jag kunde se att de ville hjälpa och jag kunde själv säga mycket. Jag hade mycket att säga till om. Men jag tror inte att samtalen skulle hjälpt någon som inte ville prata alls. Jag satt där och ville få det ur världen.

Citatet visar att det fanns en uttrycklig viljeinriktning från båda parter. Veronica, uttryckte betydelsen av ömsesidigheten i processen. Hon förmedlade att hon verkligen ville ha hjälp, det var enligt henne en förutsättning för att också få hjälp.

Förekomst av stöd, bemötande och gehör för den hjälpsökandes önskemål påverkar upplevelsen av situationen som värdig eller ovärdig. De hjälpsökande som upplever att de fått ett negativt bemötande avstår från att lämna ut känsligt material och undviker att lyfta fram problemet (Carlsson 2003). En av de avgörande faktorerna för att hjälp ska kunna ges och tas emot är i vad mån aktörerna har en gemensam syn på problemet och hjälpbehovet (a.a.). Det följande citatet visar på fenomenet samsyn. Karin (mamma) och hennes man sökte hjälp på egen hand och hade möjligheter att presentera sin problembild utan några påtryckningar:

Jag fick tvåpersoner som kom migjättenära. Från första stund så kände jag att de här kan jag lita på. Vi fick respekt för situationen.

Begreppet samklang är nära kopplat till samsyn. Samklang är hämtat från engelskans "to be attuned". Samklang kan beskrivas som ett fenomen som uppstår när människor möts på samma våglängd. Att vara i en god eller acceptabel position i ett samspel skulle kunna vara liktydigt med att vara i samklang med någon (Carlsson, 2003). Pappa Pelles beskrivning kan ses som ett uttryck för att vara i samklang med hjälparna:

Jag måste säga att när man fär den här typen av hjälp, det är ju otroligt. Det handlar om personkemin. Personkemin tror jag stämde för både mig och Karolina.

\section{Duellerande verkligheter och pseudoanpassning}

En vanlig förekommande orsak till havererande samtal och där samspelet inte fungerar kan knytas till begreppet duellerande verkligheter (Anderson 2002). Duellerande verkligheter grundar sig på antagandet att det bara finns ett sätt att betrakta världen, bara en objektiv sanning att uppdaga. När detta samspelsmönster dominerar går energin åt att försöka övertyga den andre om att den har fel. Sarah (ung tjej) deltog i samtal

Löwenborg \& Sjöblom: Föräldrars och ungdomars erfarenheter... 
tillsammans med sin mamma. I hennes berättelse duellerade hon och mamman med sina olika perspektiv mot varandra och samspelsmönstret blev ensidig och polariserande:

Det var mest att de höll med mig och mamma blev arg och så gick hon därifrån och så fick jag sitta och prata med dem (familjebehandlarna). Så slutade det mest, att hon blev arg.

Som framgår av citatet fanns ingen enighet om tolkningen av problemet. I ett duellerande samspel kan mycket energi och starka känslor gå åt till att skydda var och ens uppfattning. I det här fallet blev mamman arg och samtalet ledde snarare till att klyftan mellan henne och dottern vidgades. De olika uppfattningarna som Sarah och hennes mamma formulerade kom att framstå som duellerande verkligheter (Anderson 2002). När "fenomenet" duellerande verkligheter uppstår i hjälpprocessen finns inte längre någon korsbefruktning av idéer eller några mötesplatser för olika perspektiv. Istället kan duellerandet leda till monologiska samtal där ingen känner sig respekterad, hörd eller tagen på allvar. Inom socialt arbete kan detta få stora konsekvenser eftersom skilda perspektiv ger den aktuella problematiken olika framtoning och medför olika lösningsförslag. När den hjälpsökande och hjälparen inte kan nå fram till en samsyn, ett samverkande perspektiv och komma i samklang med varandra, om vad som är problemet får det negativa konsekvenser för den fortsatta hjälpprocessen (Carlsson 2003). I de fall när det är möjligt att nå fram till en gemensam syn så påverkar det samspelet $\mathrm{i}$ samtalen i positiv riktning.
Ett annat samspelsmönster som också påverkar bemötandet som återfanns i utsagorna från intervjuerna var det som benämns pseudoanpassning (a.a.). Om motsättningarna avseende synen på problemet inte löses så kan det hända att den hjälpsökande underkastar sig hjälparens problemdefinition och skenbart anpassar sig till situationen. Ofta handlar det om att den hjälpsökande försöker undvika tvång i något hänseende. Nästa citat visar hur en förälder pseudoanpassade sig till hjälparen när hon kände sig trängd och tvingad till att anta socialtjänstens tolkning av problemet. Lydia (mamma) lämnade motvilligt sitt medgivande till att dottern skulle placeras i familjehem:

När jag accepterade av socialkontoret att de skulle skicka min dotter till familjehem, trodde jag att familjehemmet som hon bodde $i$ skulle träffa mig och vi kunde göra någonting tillsamman, men det var inte så.

Lydia beskrev att hon slutligen gick med på att dottern skulle placeras i familjehem, utifrån rädslan att förlora inflytandet över sin dotters liv. Lydia hade hopp om att hon lättare skulle kunna samarbeta med familjehemmet om hon gick socialtjänsten till mötes. Lydia sade att hon lämnade sitt medgivande utifrån sin känsla av maktlöshet och hon uttryckte maktlöshet även senare i hjälpprocessen på detta sätt:

Vad har jag gjort för fel? Vad är jag för människa? Det är ett stort frågetecken. Är det jag som är problemet? Varför vill hon inte bo med mig? 
Citatet visar på hur Lydia förlorade sin tro på sig själv och kom att ifrågasätta sig själv både som individ och förälder.

\section{Problembestämning, supplementation, förstruktur och dialogisk rymd}

I Anderson (2002) återkommer begreppet problembestämningsprocessen, vilket är den process där hjälparen och hjälpsökande interaktivt benämner det som ska uppmärksammas i hjälpprocessen vilket bildar en ram för det som kommer att avhandlas under familjebehandlingen. Om den processen blir skev riskerar hjälpprocessen att haverera. Ett alltför snävt perspektiv stänger ute andra möjliga perspektiv, sätt att förstå och förklara den presenterade problematiken. Adam, som är pappa till en flicka, berättade om en lång tid av »här jande" efter rätt slags hjälp. Vid tidpunkten för intervjun hade Adam fått bekräftat genom att dottern fått en diagnos att tillståndet var allvarligt:

Cirkusen drogigång när hon var femton, och så ska hon hinna bli nästan tjugo år innan hon fär diagnosen. Det tycker jag är tokigt. Att man inte kan få den här utredningshjälpen via socialen eller hos någon annan. Att kompetensen saknas för att kunna undersöka och uppdaga om det faktiskt är en sjukdom hon lider av. Så efter fem års härjande så hamnade hon på akuten och då råkade vi träffa en psykiater som kände på sig att hon hade de här problemen och remitterade till rättperson. Såjag vet inte, ni kanske saknar den hos er, den här kompetensen.
Andersons (2002) tankar om problembestämningen som en viktig del i samspelet mellan den hjälpsökande och hjälparen för att hjälpprocessen inte ska haverera stämmer väl överens med Carlssons tankar om problemdefinitionen som en viktig nyckelaspekt för hur samspelsmönstret ska utvecklas. Carlsson menar att de hjälpsökande som väljer att samarbeta har ett bättre utgångsläge och större handlingsfrihet än de som inte vill etablera ett samarbete och som istället fastnar i polariserande perspektiv eller förnekar problemen och därmed mister möjligheterna att påverka processen. Definitionen av problemen är viktig för hur samspelsmönstren kommer att utvecklas och därigenom om processen kommer att leda till hjälp för den hjälpsökande eller inte.

Supplementation (Gergen refererad i Anderson 2002) är ett uttryck för hur koordinationen av uttryck och handlingar alstrar mening i samtalet. Supplementa tionsprocessen är en ömsesidig process som sker mellan den hjälpsökande och hjälparen, vilket innebär att betydelser inte är permanent fixerade utan i ständig samverkan, under konstruktion eller omkonstruktion över tid. Emmas utsaga om hur samtalen med mamman förändrade hennes syn på henne, deras relation och svårigheterna $i$ relationen, är ett exempel på supplementationsprocessen:

Jag hade en bild av hur mamma var när jag var liten, men när jag fick höra henne prata såblev bilden annorlunda. Jag märkte på en gång att det fanns många pusselbitar som fattades. När mamma berättade så kändes det som pusselbitarna föll på plats. När de 
sattes på plats där så fick jag en annan mer positiv bild av mammaän jag hade innan.

Anderson (2002) för in tankar om betydelsen av hjälparens förstruktur i sammanhanget, som en viktig aspekt i utfallet av samspelsmönster. Förstrukturen innefattar hjälparens professionella och personliga teorier, förutfattade meningar och erfarenheter, som i förväg fastställer kunskaper som hjälparen har med sig in i mötet med den hjälpsökande. När hjälparens förstruktur blir en dominerande diskurs i samtalet får den hjälpsökandes perspektiv en mer undanskymd plats, vilket kan bidra till att samspelet havererar.

Ett samverkande synsätt, som bidrar till ett hjälpsamt samspel mellan hjälpsökande och hjälparen, inkluderar begreppet en dialogisk rymd (Anderson 2002). Det syftar på ett slags metaforiskt rum mellan och inom samtalets alla deltagare, där det finns utrymme för många idéer, övertygelser och uppfattningar samtidigt. Begreppet är avgörande för hur samspelet kommer att utvecklas och gynnar flödet av olika perspektiv och handlingar.

Mikaela, en av flickorna, beskriver en situation under familjebehandlingen, som kan förstås som ett exempel på dialogisk rymd:

Familjebehandlaren har inte dragit förhastade slutsatser eller haft förutbestämda meningar eller åsikter, 'det här är orsaken'. Hon har aldrig sagt konkret av att 'jag tror att det här är orsaken', utan hon har alltid lyssnat, det var inte svart eller vit för henne.

Citatet visar hur Mikaela konkret uttryckte betydelsen av att det under familjebehandlingen skapades en möjlighet att tänka fritt och att problemets lösning arbetades fram $\mathrm{i}$ en öppen process där olika tolkningsmöjligheter var möjliga. Hon betonade också betydelsen av att hjälparen verkligen lyssnade på henne. Det i sig skapade ett utrymme för reflektion.

\section{Konklusion}

I denna artikel var syftet att undersöka hur föräldrar och ungdomar som mottagit insatsen familjebehandling inom socialtjänstens kommunala barnavård upplevde samspelet mellan familjebehandlaren och dem själva. Frågeställningar som studerats var vilka samspelsmönster som upplevdes som hjälpsamma samt vilka samspelsmönster som upplevdes som hinder för att få hjälp.

Familjebehandling är en vanligt förekommande insats för familjer som vänder sig till socialtjänsten för olika typer av relationsproblem. I artikeln har några aspekter av samspelsmönster analyserats utifrån 18 informanters upplevelser av familjebehandling och hur de upplevde bemötandet av familjebehandlarna.

Problembestämningsprocessen var en viktig faktor för hur familjebehandlingen uppfattades av den hjälpsökande. Den påverkades i sin tur av hjälparens förstruktur som kan bli en dominerande diskurs i samspelet. Analysen visade på hur problembestämningsprocessen påverkade den hjälpsökandes perspektiv. När den hjälpsökande kände sig förstådd och lyssnad på kunde detta förstås som ett samverkande perspektiv mellan hjälpare och den hjälpsö- 
kande. Begreppet är närliggande ett annat begrepp, samsyn, som definierar när hjälparens syn på problemet överensstämmer med den hjälpsökandes (Carlsson 2003). Resultaten visar på att förändringsmöjligheterna under familjebehandlingen uppstod när de olika parternas bilder av problemet och hur det skulle definieras förhandlades fram under samverkande och öppna former. Föräldrar och ungdomar uttryckte att det var viktigt att man kände sig förstådd och att hjälparen var aktivt lyssnande.

I resultaten såg vi också exempel på att samspelet präglades av olika hinder som försvårade samspelet på olika sätt. En förklaring till att negativa samspelsmönster utvecklades och att samtal havererade utgick från begreppet duellerande verklig heter (Anderson 2002).

Enligt Carlssons begreppsapparat (2003) finns flera olika möjliga förklaringar som bidrar till förståelsen av begreppet duellerande verkligheter. Han använder metaforen tolkningskrig mellan hjälparen och den hjälpsökande för att förklara när två olika synsätt kolliderar. En kollision påverkar samspelet mellan den hjälpsökande och hjälparen negativt då parterna befinner sig i en asymmetrisk relation där den hjälpsökande kan uppleva maktlöshet. Denna typ av samspelsmönster kan leda till att samtalet havererar och att hjälpen uteblir.

Pseudoanpassning är ett annat handlingsalternativ för den hjälpsökande när definitionen av problemet skiljer sig åt och då den hjälpsökande anpassar sig till hjälparens bild. Detta passiva handlingsalternativ innebär att den hjälpsökande undanhåller hjälparen information om problemet och på så vis skenanpassar sig till det alternativ som hjälparen förespråkar. I detta sammanhang påverkas samspelsmönstret av begreppet förstruktur.

Om förstrukturen dominerar i problembestämningsprocessen påverkade det utfallet av samspelet i negativ riktning. Studien visar på att problembestämningsprocessen är en central fråga för upplevelsen av ett negativt eller positivt samspel.

Det visade sig att det fanns en uppenbar risk att hjälparens definitioner kom att styra samspelet. När problembestämningsprocessen snävades in alltför snabbt så skedde det på bekostnad av den hjälpsökandes egna uppfattningar av problemet. Den hjälpsökande kunde då anpassa sig till organisationen och dess problemdefinitioner och vad den kunde erbjuda i form av olika insatser. Resultaten från den här studien visar att hjälparen utifrån sin professionella roll och det förväntade tolkningsföreträdet har ett stort ansvar för att ett öppet samspelsmönster utvecklas vilket i sin tur underlättar för att positiva hjälpprocesser ska komma tillstånd.

Familjebehandling inom socialtjänstens kommunala barnavård sker inom en given institutionell kontext som indirekt påverkar hjälpprocessen. Denna kontext präglas av starka normativa värderingar. Den byggs upp av etablerade uppfattningar om exempelvis föräldrars förmågor och barns behov av skydd från ej godtagbara uppväxtvillkor samt vad som räknas som problembeteende hos ungdomar och där samhället bör ingripa.

Familjebehandlande samtal är en insats för att åstadkomma hjälp men det är också att betrakta som institutionella samtal som är asymmetriska till sin karaktär med klara 
roller mellan den professionelle och klienten. Den professionella är »expert» och därmed i överläge i förhållande till klienten som är hjälpsökande. Resultaten från den här studien visar hur brukaren uppfattar den institutionella kontexten och hur den kan uttryckas genom den professionellas tolkningsföreträde och definitioner av problemet. Hur denna definition av problemet går till är central för upplevelsen av hjälp. En viktig kunskap som kommer fram i studien är vikten av att man som behandlare lyssnar aktivt till den hjälpsökande. Att kunna lyssna innebär en aktivitet som är något mer än att vara tyst. Lyssnande inbegriper samspel och att man under samtalet skapar ett psykologiskt utrymme som bygger på närhet, avstånd, intresse och respekt i lagom proportioner (Hydén 2008). Samspelet mellan hjälparen och den hjälpsökande framstår som en central punkt för utvecklandet av en positiv hjälpprocess. Först då när vi verkligen lyssnar på den som söker hjälp, utifrån hans eller hennes perspektiv kan positiva hjälpprocesser komma till stånd.

\section{Referenser}

Anderson, H. (2002) Samtal, språk och möjligheter - psykoterapi och konsultation ur postmodern synvinkel. Stockholm: Mareld.

Carlsson, B. (2003) Så blir det hjälp-om hjälpprocesser $i$ socialt arbete. Göteborg: Göteborgs universitet, Institutionen för socialt arbete.

De Boer, C. \& Coady, N. (2007) „Good helping relationship in child welfare». Child and family social work 12 , pp. 32-42.

Hansson, K. (2001) Familjebehandling på goda grunder. Stockholm: Centrum för utvärdering av socialt arbete (CUS) och Förlagshuset Gothia AB.

Hydén, M. (2008) "Om den svåra konsten att lyssna till berättelserı. I S. Larsson, J. Lija, \& Y. Sjöblom Narrativa metoder $i$ socialt arbete. Lund: Studentlitteratur.

Löwenborg, C. \& Kamsvåg, K. (2006) Med andra ögon - brukarens syn på familjebehandling. Ockelbo: Forskningsrapport 2006:1.

Socialstyrelsen (2003) Brukarmedverkan i socialtjänstens kunskapsutveckling. Stockholm: Socialstyrelsen.

Sundell, K. \& Egelund,T. (2001) Barnavårdsutred- ningar en kunskapsöversikt. Stockholm: Centrum för utvärdering av socialt arbete (CUS) och Förlagshuset Gothia AB.

Starrin, B. \& Jönsson, E. (2000) "Socialtjänsten och klienterna». I Meeuwisse et al. Socialt arbeteEn grundbok. Stockholm: Natur och Kultur.

Statham, J. (2000) Outcomes and Effectiveness of family support services. A reseach review. London: London University, Institute of Education.

Tengvall, K.(2000) »Inledning». I M. Berglund, S. Andréason, A. Bergmark, J. Blomqvist, L. Lindström, L. Oscarsson, G. Ågren \& A. Öjehagen (2000) Behandling av alkoholproblem. En kunskapsöversikt. Stockholm: Liber.

Wibeck, V. (2000) Fokusgrupper. Om fokuserade gruppintervjuer som undersökningsmetod. Lund: Studentlitteratur.

Överlien C., Aronsson K. \& Hydén M. (2005) »The focus group method as an in-depth method? Young woman talking about sexuality". International Journal of social research Methodology. Vol. 8, nr 4, pp. 331-334. 


\section{Summary}

\section{Parents' and young people's experiences of family treatment by social services}

In this article the authors present mothers', fathers' and young people's voices about their experiences of family treatment in the context of the social welfare office. The article focuses on the interaction patterns between the client and the helper in the family treatment process. The article is based on a quantitative research study of 268 children who have been involved with family treatment in two Stockholm municipalities and a qualitative interview study with 18 people from the same population. The experience of how the family treatment was received by the parents and their youngsters is investigated in this article. It refers to the subject's perspective on reality and the interpretative framework from which he/she made meaning of the interaction in the treatment. A common reason for the development of different interpretations and views about the interaction in family treatment and reasons why conversations were experienced as negative derives from the concept of dual/competing realities. The understanding of it is based on the assumption that there is only one correct interpretation of the world, only one objective truth to be discovered.

Another interaction pattern which also emerged from the analysis was a breakdown in the conversation that was due to false accommodation. If the client did not openly express his or her hidden definition of the problem he or she could align with the helper's definition and appear to go along with it. However, when the client felt understood and listened to, an interaction pattern that was collaborative and cooperative between the helper and the client took place. This pattern made it possible for clients to start a process of change. The potential for change was dependent on each person's individual picture of reality becoming apparent. That could open for a new mutual sharing process. The changing process was also closely connected to the definition of the problem. How the problem was defined was revealed to be an important factor in developing an interaction pattern that was experienced as positive and that could lead to a successful family treatment process. 